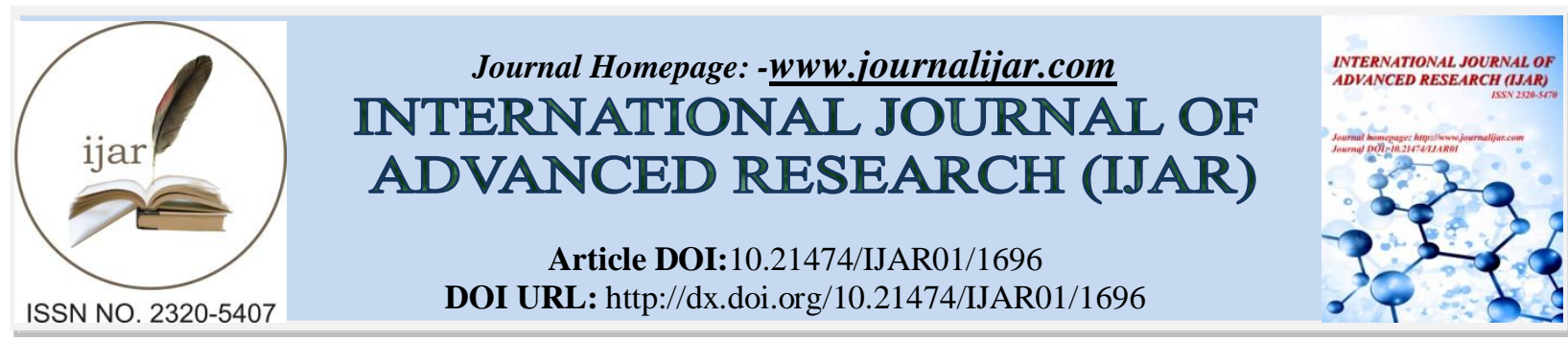

RESEARCH ARTICLE

\title{
EFFECT OF DIFFERENT LEVELS OF DRIED RUMEN CONTENT ON NUTRIENT INTAKE, DIGESTIBILITY AND GROWTH PERFORMANCE OF AWASSI LAMBS.
}

Anmar A. Majeed Al-Wazeer

Department of Animal Production, Faculty of Agriculture, University of Kufa, Al-Najaf, Iraq.

\section{Manuscript Info}

Manuscript History

Received: 12 July 2016

Final Accepted: 19 August 2016

Published: September 2016

Key words:-

Rumen content, Nutrient intake,

Apparentdigestibility, Growth

performance,Awassi lambs

\section{Abstract}

This study was conducted to investigate the effect of feeding dry rumen content (DRC) at different levels on nutrient intake, digestibility and growth performance of Awassi lambs. Twelve Awassi lambs $(22.27 \pm 0.25 \mathrm{~kg}$ body weight and 4 months old) were randomly allotted into four diets for 65 days. The DRC was included in the diets at $0 \%$ (DRC0), 10\% (DRC10), 20\% (DRC20), 30\% (DRC30) to replace parts of the barley grain and soybean meal in the concentrate diet. On the day 60 of the experimental period, all lambs were fitted with fecal collection bags to evaluate the nutrient digestibility. Intake of dry matter (DM), organic matter (OM) and Metabolizable energy (ME) were not affected $(\mathrm{P}>0.05)$ in lambs fed DRC10 and DRC20 diets compared to those fed DRC0 (control) diet but decreased $(\mathrm{P}<0.05)$ in lambs fed DRC30 diet. Intake of $\mathrm{CP}(\mathrm{g} /$ day $)$ was higher $(\mathrm{P}<0.05)$ in lambs fed DRC10 and DRC20 diet than those fed DRC30 diet, but not significant difference $(\mathrm{P}>0.05)$ than those fed control one (DRC0) while, intake of $\mathrm{CP}\left(\mathrm{g} / \mathrm{kg} \mathrm{W}^{0.75}\right)$ did not differ $(\mathrm{P}>0.05)$ among diets. Intakes of neutral detergent fiber (NDF) and acid detergent fiber $(\mathrm{ADF})$ were highest $(\mathrm{P}<0.01)$ for lambs fed the DRC30 diet followed by the DRC20 and DRC10 than those fed DRC0. No significant different in DM, OM, CP, NDF and ADF digestibility. Total gain and average daily gain (ADG) in lambs fed DRC10 and DRC 20 diets were not significant $(P>0.05)$ different as compared with lambs fed DRC0 (control) diet but they were decreased $(\mathrm{P}<0.05)$ when lambs fed DRC30 diet. Lambs fedDRC10 diet was higher $(\mathrm{P}<0.05)$ in feed efficiency than those fed DRC30, but no significant $(\mathrm{P}>0.05)$ difference than those fed DRC0 and DRC20 diets. It could be concluded that feeding Awassi lambs diets containing DRC up to $10 \%$ improved growth performance without any adverse effect on nutrient digestibility or animal health.

Copy Right, IJAR, 2016,. All rights reserved. 


\section{Introduction:-}

In Iraq, using agricultural and industrial by-products in feeding livestock has increased tremendously (Hassan et al., 2013; Hassan and Abass, 2014) due to the shortage of conventional feedstuffs such as barley grain and soybean meal. They are the major components of concentrate diet locally used. Recently, the prices of cereal and traditional protein concentrate have risen steadily, leading to increase the cost of animal feeding and production. Therefore, extensive research interests have been carried on to investigate for cheaper non-conventional feed ingredients (Khattab et al., 2011; Nasser et al., 2012). One of such is from slaughterhouse by-product comprising rumen contents. Rumen contents are abundantly available as slaughterhouse by-product and mainly considered as waste material creating environmental pollution (Abouheif et al., 1999; Cherdthong and Wanapat, 2013). Usually, rumen contents are cheap to purchase from slaughterhouse with drying and shipping are the most important added costs when used in livestock feeding (Khan et al., 2014). Rumen contents are rich in microbial cell, crude protein and contain digested plant material at various stages of fermentation, saliva, amino acids, vitamins, and end products of rumen fermentation as reported in previous studies (Rao and Fontenot, 1987; El-Yassin et al., 1991; Abouheif et al., 1999; Olafadehan et al., 2014, Cherdthong et al., 2015). In addition, it's rich in minerals (Elfaki and Abdelatti, 2015). The use of DRC is not the new concept and not routinely used in feeding livestock due to low palatability and the moderate level of crude protein and some parts of indigestible fiber (Khattab et al., 2011; Talib et al., 2016). In addition, to high moisture content (Abouheif et al., 1999). Several methods are used to overcome this limitation such as oven drying, sun drying, mixed with blood, barley grain and molasses (El-Yassin et al., 1991; Abouheif et al., 1999, Khan et al., 2014), ensiled with crop residue with urea and molasses(Khan et al., 2014;Talib et al., 2016) and adding exogenous fibrolytic enzymes (Khattab et al., 2011), but the effective and cheapest methods was sun drying (Khattab et al., 1996;Osman and Abass, 2015). Moreover, Cherdthong and Wanapat (2013) revealed that supplementation of DRC in concentrate diets resulted in improved in vitrodry matter and organic matter digestibility in buffalo rumen fluid. This study is one of few studies were done on the use of DRC in Awassi lambs. Therefore, the objective of this study was to investigate the effects of replacement parts of barley grain and soybean meal with dried rumen content (DRC) on, nutrients intake, digestibility and growth performance of Awassi lambs.

\section{Materials and Methods:-}

\section{Preparation of dried rumen content (DRC):-}

Bovine rumen contents were obtained from local the slaughterhouse (mainly cattle). Slaughtered cattle were examined before slaughtered by the veterinary to ensure not transmitted of infectious diseases. Rumen contents materials were collected from the visceral of cattle was opened without contamination of blood and separated over a concrete surface and allowed to sun air-dry for 5 days to reduce the moisture content then milled using hammer mill to produce finely ground dried rumen content (DRC) and mixing with other dietary ingredients.

\section{Diets, experimental animal and their management:-}

Twelve Awassi male lambs with initial body weight (BW) $22.27 \pm 0.25 \mathrm{~kg}$ and 4 months old were obtained from the sheep flock maintained at the Animal field, Faculty of Agriculture, University of Kufa, Najaf, Iraq $\left(31^{\circ} 7^{\prime} \mathrm{N}, 4^{\circ} 48^{\prime}\right.$ E). All Lambs were vaccinated against internal and external parasites before the experiment started. Lambs were randomly distributed into four treatment groups (3 lambs each) using a completely randomized design and housed in the semi-shaded individual pens $(1.5 \mathrm{~m} \times 1.5 \mathrm{~m})$ and fed once daily at $8.00 \mathrm{am}$. The experiment lasted 60 days during which the animal allowed adapting the individual pens and the experimental diets. Animals had free access to fresh water throughout the experiment. The diets consisted of four concentrate diets replacement levels of concentrate (barley grain and soybean meal) by DRC at 0, 10, 20 and 30\% on DM basis. All diets were formulated to be similar in crude protein content. The concentrate diets were offered at $3 \%$ of BW while alfalfa hay was offered ad libitum. Daily feed intake and refusal feed from each lamb were recorded before morning feeding to determine the voluntary feed intake. Lambs were weighed at the beginning of the experiment and every 14 days to determine changes in live weight. The last week of the experimental period was used for digestibility trail, using same lambs with same dietary treatments. Lambs were fitted with facial collection bags (locally manufacture) for 2 days as an adaptation period followed by 5 days for feces collection. Daily fecal output was collected, weighed, and recorded. Representative samples $(10 \%)$ of feces were collected over conclusive days, stored at $-18^{\circ} \mathrm{C}$. On the last day of the collection period, the composite feces samples were thawed and thoroughly mixed and subsamples were dried at $55^{\circ} \mathrm{C}$ in a forced- air oven for $48 \mathrm{~h}$ and ground to pass through $1-\mathrm{mm}$ screen and kept for chemical analysis. Samples of feed offered and feed refused were also collected every day and sub-sampled and ground (1 mm screen) and kept for analysis. 


\section{Chemical Analysis:-}

Samples of feed, DRC and alfalfa hay were ground passing a $1 \mathrm{~mm}$ screen and analyzed in triplicate for dry matter (DM method 930.15), ash (method 924.05), crude protein (CP, Kjeldahl N $\times 6.25$, method 984.13), ether extract (EE, method 920.39) and, crude fiber (CF method 973.18) by the procedures of AOAC (1995). Nitrogen-free extract (NFE) were calculated by difference. Neutral detergent fiber (NDF), acid detergent fiber (ADF) and acid detergent lignin (ADL) was determined according to the procedure described by Van Soest et al. (1991) with sodium sulfite but not alpha amylase for NDF determination. Both NDF and ADF expressed were inclusive of residual ash.

\section{Statistical analysis:-}

All data were subjected to statistical analysis of variance using SAS software (SAS, 2004) with the following model: $Y_{i j}=\mu+T_{i}+e_{i j}$, where $Y_{i j}$ : observed variation, $\mu$ : population means, $T_{i}$ : effect of replacement levels ${ }_{i}$ the diets and $e_{i j}$ : error term. Significant differences among treatment means were tested by Duncan's multiple range test (Duncan, 1955) using the same software.

\section{Results and Discussion:-}

\section{Chemical composition:-}

The chemical composition of experimental diets and dried rumen contents (DRC) are presented in Table 1. Dry matter (DM), crude protein (CP) and ether extract (EE) contents were similar among experimental diets, while the neutral detergent fiber (NDF), acid detergent fiber (ADF), acid detergent lignin (ADL), crude fiber (CF) and ash contents were increased as level of DRC increased. This may be due that DRC contains more fiber fraction such as lignin than barley grain and soybean meal. DRC contain semi-fermented feed ingredient in the rumen of slaughtered animal. These results are in the line of reported by several authors (Rios-Rincon et al.,2010; Cherdthong et al., 2014; Olafadehan et al., 2014) when incorporated DRC in the diets of steers and sheep. The DRC used in the current study contained $(14.22 \% \mathrm{CP})$. This value is within the range 13.3-16.4\% in rumen content from cattle reported by Abouheif et al.(1999). Similar results were reported by many investigators (Rezakhani et al., 2008; Rios-Rincon et al., 2010; Nasser et al., 2012; Olafadehan et al., 2014; Talib et al. 2016), but lower than reported by several authors (Agbabiaka et al., 2012; Cherdthong and Wanapat, 2013; Cherdthong et al., 2014; Elfaki and Abdelatti, 2015). They reported that $\mathrm{CP}$ content in DRC from cattle ranged from 16.4-19.56\%. These variation in chemical composition of DRC may be due to several factors such as pre-slaughter feeding regimen, length of holding period between feeding and slaughter (Abouheif et al.,1999; Rios-Rincon et al.,2010; Cherdthong and Wanapat, 2013; Cherdthong et al. 2014), season of the year (Rezakhani et al., 2008). Moreover, it may be related type of feed resources diversity and selectivity of pasture by different ruminants in the different locations (Agbabiaka et al., 2012; Elfaki and Abdelatti, 2015). Chemical composition could be varying by species of ruminants (Abouheif et al., 1999; Agbabiaka et al., 2012; Elfaki and Abdelatti, 2015). In this sense, the rumen contents used in the current study were obtained from slaughtered cattle without contamination of blood that may influence the CP value in DRC.

Table 1:-The ingredients and chemical composition of the dietary treatments and dried ruminal content fed to Awassi lambs.

\begin{tabular}{|l|c|c|c|c|c|}
\hline \multirow{2}{*}{ Item } & \multicolumn{4}{c|}{ Diet } & \multirow{2}{*}{ DRC $^{\mathbf{1}}$} \\
\cline { 2 - 5 } & DRC0 & DRC10 & DRC20 & DRC30 & \\
\hline Ingredient (\% DM) & & & & & \\
\hline Alfalfa hay & 30 & 30 & 30 & 30 & \\
\hline Barley grain & 43.9 & 34.9 & 25.9 & 16.9 & \\
\hline Soybean meal & 14 & 13 & 12 & 11 & \\
\hline Dried rumen content (DRC) & 0 & 10 & 20 & 30 & \\
\hline Wheat bran & 10 & 10 & 10 & 10 & \\
\hline Salt and limestone & 2 & 2 & 2 & 2 & \\
\hline Premix & 0.1 & 0.1 & 0.1 & 0.1 & \\
\hline Chemical composition (\% DM) & & & & & \\
\hline DM & 89.53 & 89.79 & 90.05 & 90.31 & 91.60 \\
\hline OM & 93.05 & 91.81 & 90.75 & 89.6 & 85.5 \\
\hline Ash & 6.95 & 8.19 & 9.25 & 10.40 & 14.5 \\
\hline CP & 16.57 & 16.61 & 16.64 & 16.68 & 14.22 \\
\hline CF & 12.34 & 14.68 & 17.01 & 19.34 & 29.10 \\
\hline NFE & 60.8 & 57.06 & 53.51 & 49.86 & 38.89 \\
\hline
\end{tabular}




\begin{tabular}{|l|c|c|c|c|c|}
\hline EE & 2.34 & 2.46 & 2.59 & 2.72 & 3.29 \\
\hline NDF & 33.49 & 36.67 & 39.85 & 43.02 & 53.00 \\
\hline ADF & 16.42 & 19.00 & 21.57 & 24.14 & 32.88 \\
\hline ADL & 4.15 & 5.24 & 6.33 & 7.43 & 10.45 \\
\hline $\mathrm{ME}(\mathrm{MJ} / \mathrm{kg} \mathrm{DM})^{3}$ & 11.96 & 11.60 & 11.26 & 10.91 & 9.63 \\
\hline
\end{tabular}

1. Dried rumen content (DRC) included in the diets at 0 (DRC0), 10 (DRC10), 20 (DRC20), and 30\% (DRC30)

2. Composition per $1 \mathrm{~kg}$ contained: vitamin A, 500,000 IU; vitamin D3, 100,000 IU; vitamin E, 250mg; Fe, $5.0 \mathrm{~g}$; $\mathrm{Cu}, 1.0 \mathrm{~g}$; Co, $10.0 \mathrm{mg}$; Se, $10.0 \mathrm{mg}, \mathrm{Mn}, 5.0 \mathrm{~g}, \mathrm{Mg} 15.0 \mathrm{~g} ; \mathrm{Zn} 5.0 \mathrm{~g}$ plus antioxidant.

3. Metabolizable energy was calculated ME $(\mathrm{MJ} / \mathrm{kg} \mathrm{DM})=0.012 \mathrm{CP}+0.031 \mathrm{EE}+0.005 \mathrm{CF}+0.014 \mathrm{NFE}$ (MAFF, 1975).

$\mathrm{DM}=$ dry matter; $\mathrm{OM}=$ organic matter; $\mathrm{CP}=$ crude protein; $\mathrm{EE}=$ ether extract; $\mathrm{NDF}=$ neutral detergent fiber; $\mathrm{ADF}=$ acid detergent fiber; $\mathrm{ADL}=$ acid detergent lignin; $\mathrm{CF}=$ crude fiber, $\mathrm{NFE}=$ nitrogen free extract.

Nutrient intake, apparent digestibility and nutritive value:-.

All lambs readily consumed concentrate diets and finish the experiment period, no health problem was detected. Similar results were reported in lambs (Salinas-Chavira et al., 2007; Fajemisin et al., 2010; Olafadehan et al., 2014; Osman and Abass, 2015) and in cattle (Cherdthong et al., 2014) when incorporation DRC in the diet. Mondal et al. (2013) observed that feeding DRC did not show any undesirable effect on goat's health.

Replacement parts of barley grain and soybean meal with DRC had no significant effect $(P>0.05)$ on DM, OM, and ME intake in lambs fed DRC10 and DRC20 diets compared to those fed DRC0 (control) diet(Table 2). This may be due to lower replacement rate of DRC. Similar results reported by Osman et al. (2015) when fed Shugor desert lambs at different levels of DRC (0, 5 and 10\%). Mondal et al. (2013) also found incorporation DRC instead of wheat bran in Bengal goat diet at level 10\% did not affect DM and OM intake compared to control diet. However, intakes of DM and OM in Lambs fed DRC30 diet were lower $(\mathrm{P}<0.05)$ as compared with those fed DRC0, DRC10 and DRC20 diets when expressed as g/day while these different disappear when expressed as $\mathrm{g} / \mathrm{kgW}^{0.75}$ (Table 2). These results disagreed with results reported by Abouheif et al. (1999) who found no differences in DM intake when fattening Najdi lambs fed diets containing DRC at levels of 25 and 50\% compared to lambs fed control diet. In addition, Cherdthong et al. (2014) reported no difference in intakes of DM and OM of Thai cattle when soybean meal was replaced by DRC at the different ratio. However, Salinas-Chavira et al. (2007) found that DM intake increased significantly in Pelibuy $\times$ Dorper lambs fed 4\% DRC as compared with those fed control one. Osman and Abass (2015) reported that DM intake increased for Sudan desert lambs fed 20\% DRC compared with lambs fed 0 and $10 \%$ DRC. In another study, when dried rumen contents were included at different levels $(0,20,40$, and $60 \%)$ in diets for Yankasa lambs, Olafadehan et al. (2014) observed increased DM and OM intakes up to 40\% DRC. In agreement with the results obtained in the current study the higher replacement rate of DRC impacted negatively on DM and OM intake. Nasser et al. (2012) observed that DM intake decreased in calves fed DRC at level $16 \%$ versus calves fed lower levels of DRC (0 and 8\%). Moreover, Olafadehan et al. (2014) observed that feed consumption was lower in Yankasa lambs fed DRC at the level of 60\% than those fed the control diet. Abouheif et al. (1999) also observed a reduction in feed intake in Najdi lambs fed a diet contained $100 \%$ DRC. Intake of CP (g/day) was higher $(\mathrm{P}<0.05)$ in lambs fed DRC10 and DRC20 diet than those fed DRC30 diet, but not significant difference $(\mathrm{P}>0.05)$ than those fed control one (DRC0) while, intake of $\mathrm{CP}\left(\mathrm{g} / \mathrm{kg} \mathrm{W}^{0.75}\right)$ did not differ $(\mathrm{P}>0.05)$ among diets. Similar results reported lambs (Abouheif et al., 1999), in goats (Mondal et al., 2013) with no difference in CP intake. Intake of NDF and ADF were highest $(\mathrm{P}<0.01)$ in lambs fed DRC30 and DRC20 diets followed by DRC10 and DRC0 diets (Table 2). The higher NDF and ADF intakes for DRC diets can be explained by the differences in NDF and ADF contents (Table 1). Similarly, Olafadehan et al. (2014) observed that NDF and ADF intakes were increased when lambs fed at 20 and $40 \%$ DRC compared to those fed free of DRC. Inconsistent, with results reported by Cherdthong et al. (2014) who found that intakes of NDF and ADF were not affected in Thai cattle fed different level of DRC as compared with those fed control diet. A large variation observed with very limited published data could be attributed to the considerable variation in chemical composition DRC previously discussed in chemical composition. In addition, there were variations in processing rumen content such as mixed rumen content with barley grain (Abouheif et al., 1999) or mixed with blood and molasses (El-Yassin et al., 1991; Fajemisin et al., 2010; Khan et al., 2014). 
No significant difference $(\mathrm{P}>0.05)$ in digestibility coefficient of $\mathrm{DM}, \mathrm{OM}, \mathrm{CP}$, NDF and ADF at lambs was observed in response to increase replacement parts of barley grain and soybean meal by DRC (Table 2). Similar results reported by Mondal et al. (2013) who found that DM, OM, CP and NDF digestibility was not affected by increasing levels of DRC in the diet of Black Bengal goats (i.e. 0, 5 and 10\%). Similar results also reported by Cherdthonget al. (2014) when replaced soybean meal with DRC at different levels of DRC in thecattle diet. Kamstra et al. (1959) also reported that DM, CP and CF digestibilities were not affected between lambs fed control and DRC diets. In contrast, Abouheif et al. (1999) reported that CP digestibility was higher in Najdi lambs fed $25 \%$ of rumen content-barley meal in Najdi lambs diets as compared with those fed control one. Fajemisin et al. (2010) also found increased CP digestibility when fed Dwarf sheep on diet containing 25\% DRC but reported decease in DM, NDF and ADF digestibility. In addition, Olafadehan et al. (2014) observed increase digestibility of DM, OM, CP in lambs fed 20 and $40 \%$ DRC than lambs fed 0 and $60 \%$ DRC. The same authors reported that NDF and ADF digestibility were not affected. Rios-Rincon et al. (2010) found decrease in ruminal and total tract digestibility of OM and ADF when used DRC instead of alfalfa hay in cattle ration. Great variation also found in digestibility of nutrient due to such factors roughage to concentrate ratio, levels of DRC, chemical composition of DRC, and diets in addition to source of rumen content and processing methods that affected nutrient digestibility (Kamstra et al.,1959; Agbabiaka et al., 2012;Mondal et al., 2013; Elfaki and Abdelatti, 2015). A significant ( $\mathrm{P}<0.05)$ reduction in ME intake was observed for lambs fed DRC30 diets compared to those fed other diets (DRC0, DRC10 and DRC20), but no significant difference among DRC0, DRC10 and DRC20 diets (Table2) may be due to higher content of fiber fraction in DRC and replacement rate. Digestible crude protein (DCP) value was not significantly different $(\mathrm{P}>0.05)$ among experimental diets and numerically higher in DRC10 and DRC20 diets than DRC0 and DRC30 diets. A similar trend was observed for digestible crude protein intake (Table 2). This result may be due to the not significant difference in CP digestibility in the current study. The digestible organic matter intake (DOMI) and digestible organic matter fermented in the rumen (DOMR) were not affected $(\mathrm{P}>0.05)$ among experimental diets. The numerical increase in DCP value, DOMI, DOMR ME intake in DRC10 diet attributed to superior nutritive value.

Table 2:-Nutrient intake, apparent digestibility and nutritive valueof Awassi lambs fed diets containing graded levels of DRC ${ }^{1}$

\begin{tabular}{|c|c|c|c|c|c|c|}
\hline \multirow[t]{2}{*}{ Item } & \multicolumn{4}{|c|}{ Diets } & \multirow[t]{2}{*}{ SEM } & \multirow[t]{2}{*}{ Sign. } \\
\hline & DRC0 & DRC10 & DRC20 & DRC30 & & \\
\hline \multicolumn{7}{|l|}{ Nutrient intake } \\
\hline DM intake (g/day) & $1024.97^{\mathrm{a}}$ & $1033.86^{\mathrm{a}}$ & $1027.73^{\mathrm{a}}$ & $1007.80^{b}$ & 3.38 & * \\
\hline$\left(\mathrm{g} / \mathrm{kgW}^{0.75}\right)$ & 87.00 & 87.27 & 87.07 & 86.30 & 0.61 & NS \\
\hline OM intake(g/day) & $953.73^{\mathrm{a}}$ & $949.19^{\mathrm{a}}$ & $932.66^{\mathrm{a}}$ & $902.99^{b}$ & 6.20 & $*$ \\
\hline$\left(\mathrm{g} / \mathrm{kgW}^{0.75}\right)$ & 80.95 & 80.10 & 79.01 & 77.33 & 0.68 & NS \\
\hline $\mathrm{CP}$ intake(g/day) & $169.84^{\mathrm{ab}}$ & $171.72^{\mathrm{a}}$ & $171.01^{\mathrm{a}}$ & $168.10^{\mathrm{b}}$ & 0.50 & * \\
\hline$\left(\mathrm{g} / \mathrm{kgW}^{0.75}\right)$ & 14.42 & 14.49 & 14.49 & 14.40 & 0.99 & NS \\
\hline EE intake(g/day) & $23.98^{\mathrm{b}}$ & $25.43^{\mathrm{ab}}$ & $26.62^{\mathrm{a}}$ & $27.41^{\mathrm{a}}$ & 0.39 & $*$ \\
\hline NDF intake(g/day) & $343.26^{\mathrm{c}}$ & $379.12^{\mathrm{b}}$ & $409.55^{\mathrm{b}}$ & $433.55^{\mathrm{a}}$ & 9.22 & $* *$ \\
\hline ADF intake(g/day) & $168.30^{c}$ & $196.43^{\mathrm{c}}$ & $221.68^{\mathrm{b}}$ & $243.28^{\mathrm{a}}$ & 8.45 & ** \\
\hline \multicolumn{7}{|l|}{ Digestibility (\%) } \\
\hline $\mathrm{DM}$ & 71.09 & 71.83 & 69.48 & 69.29 & 0.98 & NS \\
\hline $\mathrm{OM}$ & 73.47 & 74.38 & 73.76 & 71.50 & 0.86 & NS \\
\hline $\mathrm{CP}$ & 73.41 & 75.13 & 74.08 & 72.98 & 1.43 & NS \\
\hline $\mathrm{EE}$ & 73.65 & 74.70 & 74.45 & 71.76 & 0.99 & NS \\
\hline $\mathrm{NDF}$ & 62.25 & 62.36 & 62.23 & 60.77 & 1.62 & NS \\
\hline $\mathrm{ADF}$ & 55.47 & 53.40 & 51.43 & 50.05 & 1.08 & NS \\
\hline \multicolumn{7}{|l|}{ Nutritive value } \\
\hline $\mathrm{DCP}(\%)$ & 12.16 & 12.48 & 12.33 & 11.62 & 0.20 & NS \\
\hline Digestible DM intake (g/day) & 728.79 & 742.47 & 714.07 & 698.37 & 9.86 & NS \\
\hline Digestible OM Intake (g/day) & 700.87 & 705.86 & 687.95 & 645.68 & 9.48 & NS \\
\hline Digestible CP Intake (g/day) & 124.70 & 128.98 & 126.69 & 117.09 & 2.20 & NS \\
\hline DOMR(g/day) & 455.57 & 458.21 & 447.17 & 419.69 & 6.82 & NS \\
\hline ME intake (MJ/day) & $11.76^{\mathrm{a}}$ & $11.99^{\mathrm{a}}$ & $11.84^{\mathrm{a}}$ & $10.99^{\mathrm{b}}$ & 0.19 & $*$ \\
\hline
\end{tabular}

Diets: Dried rumen content (DRC) included in the diets at 0 (DRC0), 10 (DRC10), 20 (DRC20), and 30\% (DRC30) 
${ }^{\mathrm{a}, \mathrm{b}, \mathrm{c}}$ Mean within the same row with different subscripts are differ $(\mathrm{P}<0.05) ; \mathrm{SEM}=$ standard error of mean; NS= not significant;

$*=\mathrm{P}<0.05 ; * *=\mathrm{P}<0.01 ; \mathrm{DM}=$ dry matter; $\mathrm{OM}=$ organic matter; $\mathrm{CP}=$ crude protein; $\mathrm{EE}=$ ether extract; $\mathrm{NDF}=$ neutral detergent fiber; $\mathrm{ADF}=$ acid detergent fiber; Digestible organic matter fermented in the rumen (DOMR) was calculated according to the equation DOMR $(\mathrm{g} /$ day $)=$ digestible organic matter intake $(\mathrm{g} /$ day $) \times 0.65($ ARC, 1984)

\section{Growth performance:-}

Initial, final body weight (BW), total gain, average daily gain (ADG) and feed conversion ratio (FCR) of the lambs fed graded levels of DRC are presented in Table 3. Statistical analysis revealed that no significant different $(\mathrm{P}>0.05)$ in final BW of lambs among experimental diets. Total gain and average daily gain (ADG) in lambs fed DRC10 and DRC 20 diets was not significant ( $\mathrm{P}>0.05$ ) different as compared with lambs fed DRC0 (control) diet. These results are in the line reported by Mondal et al. (2013) and Osman et al. (2015) who found that inclusion of DRC in diets at 0, 5 and 10\% DRC did not affect final live weight and ADG in kids and lambs. Osman and Abass (2015) also observed that feeding Sudan desert lambs on diet that contained DRC at 0, 10 and 20\% did not affect final body weight, total gain and ADG. Salinas-Chavira et al. (2007) reported no different in ADG and feed efficiency of Pelibuy $\times$ Dorper lambs fed DRC. However, Abouheif et al. (1999) found that ADG was lower in Najdi lambs fed 25 and $50 \%$ dry rumen content- barley meal diets than those fed the control diet. While Olafadehan et al. (2014) reported that body weight gain and ADG in Yankasa lambs were increased as levels of DRC increase from 0 to $40 \%$ but decreased at 60\% DRC. Fajemisin et al. (2010) also reported that replacement cassava peels by DRC at 25\% did not affect on ADG in West African Dwarf sheep. The decrease in feed intake observed for lambs fed DRC30 diet resulted in lower $(\mathrm{P}<0.05)$ total weight gain and ADG compared to those fed the DRC0, DRC10 and DRC20 diet (Table3).

Regards, feed conversion ratio (FCR) or feed efficacy (DMI:ADG), Lambs fedDRC10 diet was higher $(\mathrm{P}<0.05)$ in feed efficiency than those fed DRC30 diet, but no significant $(\mathrm{P}>0.05)$ difference than those fed DRC0 and DRC20 diets. Similarly, Osman et al. (2015) reported that feed efficiency was higher when incorporate DRC in concentrate diet at $10 \%$ than lambs fed 0 and 5\% DRC, but the different not significant. A similar trend was noted when included DRC at different levels (0,10 and 20\%) in the diet of Sudan desert lambs (Osman and Abass, 2015).In contrast with results reported by Mondal et al. (2013)who found that Black Bengal goats showed higher feed efficiency in control diet than those fed DRC diets(5 and 10\% ). Abouheif et al. (1999) also reported similar results in Najdi lambs fed rumen content- barley meal diet (25 and 50\%). In another study, Olafadehan et al. (2014) observed that feed efficiency was higher in lambs fed 40\%DRC than those fed 0 and $20 \%$ DRC, but decreased $(\mathrm{P}<0.05)$ when lambs fed 60\% DRC diet. The higher feed efficiency at the lower level of DRC $10 \%$ may be due to better utilization of nutrients intakes.

Table 3:-Growth performance of Awassi lambs fed diet containing graded levels of DRC.

\begin{tabular}{|l|c|c|c|c|c|c|}
\hline \multirow{2}{*}{ Item } & \multicolumn{3}{|c|}{ Diets } & \multirow{2}{*}{ SEM } & \multirow{2}{*}{ Sign. } \\
\cline { 2 - 6 } & DRC0 & DRC10 & DRC20 & DRC30 & & \\
\hline Initial BW(kg) & 22.27 & 22.23 & 22.30 & 22.28 & 0.25 & NS \\
\hline Final BW(kg) & 31.40 & 31.83 & 31.50 & 30.73 & 0.27 & NS \\
\hline Total weight gain (kg) & $9.13^{\mathrm{a}}$ & $9.60^{\mathrm{a}}$ & $9.20^{\mathrm{a}}$ & $8.45^{\mathrm{b}}$ & 0.15 & $*$ \\
\hline Average daily gain (g) & $152.22^{\mathrm{a}}$ & $159.99^{\mathrm{a}}$ & $153.33^{\mathrm{a}}$ & $140.84^{\mathrm{b}}$ & 2.45 & $*$ \\
\hline FCR (g DMI/g ADG) & $6.74^{\mathrm{ab}}$ & $6.46^{\mathrm{b}}$ & $6.71^{\mathrm{b}}$ & $7.17^{\mathrm{a}}$ & 1.00 & $*$ \\
\hline
\end{tabular}

Diets: Dried rumen content (DRC) included in the diets at 0 (DRC0), 10 (DRC10), 20 (DRC20), and 30\% (DRC30).

${ }^{\mathrm{a}, \mathrm{b}, \mathrm{c}}$ Mean within the same row with different subscripts are differ $(\mathrm{P}<0.05)$; $\mathrm{SEM}=$ standard error of mean; NS= not significant;

*= $\mathrm{P}<0.05 ; \mathrm{BW}=$ body weight; $\mathrm{ADG}=$ average daily gain; $\mathrm{FCR}=$ feed conversion ratio (dry matter intake/average daily gain)

This study is one of few studies that investigated the replacement part of barley grain and soybean meal with dried rumen content on the nutrient digestibility and growth performance of Awassi lambs base on the results obtained in this study it could be concluded that feeding Awassi lambs fattening on diets containing DRC up to $10 \%$ improved growth performance without any adverse effect on nutrient digestibility or animal health. The lower price of DRC compared with barley grain and soybean meal suggested that replacement the most expensive ingredient with DRC would help increase economic return and reduce pollution problems. 


\section{References:-}

1. Abouheif, M.A., Kraidees, M.S. and Al-Selbood, B.A. (1999). The utilization of rumen content-barley meal in diets of growing lambs. Asian-Aus. J. Anim. Sci. 12(8): 1234-1240.

2. Agbabiaka, L.A., Madubuike, F.N. and Amadi, S.A. (2012). Studies on nutrients and anti-nutrients of rumen digesta from three most domesticated ruminants in Nigeria. Pak. J. Nutr., 11(7):580-58.

3. AOAC.(1995). Official Methods of Analysis. $16^{\text {th }}$ ed. Association of Official Analytical Chemists. Arlington, VA, USA.

4. ARC, (1984). Nutrient requirements of the ruminant livestock. Supplement No. 1. Commonwealth Agricultural Bureau, Slough, UK

5. Cherdthong, A. and Wanapat, M. (2013). Manipulation of in vitro ruminal fermentation and digestibility by dried rumen digesta. Livest.Sci., 153:94-100.

6. Cherdthong, A., Wanapat, M., Saenkamsorn, A., Supapong, C., Anantasook, N. and Gunun, P. (2015). Improving rumen ecology and microbial population by dried rumen digesta in beef cattle. Trop. Anim. Health. Prod. 47(5):921-926.

7. Cherdthong, A., Wanapat, M., Saenkamsorn, A., Waraphila, N., Khota, W., Rakwongrit, D. Anantasook, N., and Gunun, P. (2014).Effects of replacing soybean meal with dried rumen digesta on feed intake, digestibility of nutrients, rumen fermentation and nitrogen use efficiency in Thai cattle fed on rice straw.Livest.Sci., 169:71-77.

8. Duncan, D.B. (1955). Multiple ranges and Multiple F. test. Biometrics, 11: 1-42.

9. Elfaki, M.O.A. and Abdelatti, K.A. (2015). Nutritive evaluation of rumen content from cattle, camel, sheep and goats. Global J. Anim. Sci. Res., 3(3):617-621.

10. El-Yassin, F.A., Fontenot, J.P. and Chester-Jones, H. (1991). Fermentation characteristics and nutritional value of ruminal contents and blood ensiled with untreated or sodium hydroxide-treated wheat straw. J.Anim.Sci., 69:1751-1759.

11. Fajemisin, A.N., Fadiyimu, A.A. and Alokan, J.A. (2010). Dry matter, fiber consumption and body weight gain of West African Dwarf sheep fed sun-dried of fermented rumen digesta- poultry droppings mixed diets. App.Trop.Agric., 15(1\&2):84-89.

12. Hassan, S.A. and Abass, I.R. (2014). Effect of substitution date by barley with two sources of nitrogen on intake, live weight gain, feed conversion ratio and digestion coefficients. Iraqi J.Agric.Sci., 45(6): 555-565.

13. Hassan, S.A., Al-Baiati, H.Y. and Al-Mosawy, J.E. (2013). Effect of substitution of barley by whole dates on performance and digestion of Awassi lambs. KSU J. Nat. Sci., 16(3):12-15.

14. Kamstra, L.D., Zimmer, P.R. and Embry, L.B. (1959). Feeding value and activity of dried rumen products. J. Anim. Sci., 18:849-854.

15. Khan, M.W., Pasha, T.N., Koga, A., Anwar, S., Abdullah, M. and Iqbal, Z. (2014). Evaluation and utilization of rumen content for fattening of Nili-Ravi male calves. J. Anim. Plant Sci., 24(Suppl. 1):40-43.

16. Khattab, H.M., Abdelmawla, S.M. and Singer, A.M. (1996). Nutritional evaluation of rumen contents as a slaughterhouse waste in sheep rations. Egyptian J. Anim. Prod. (suppl.) 33: 173-186.

17. Khattab, H.M., Gado, H.M., Kholif, A.E., Mansour, A.M and Kholif, A.M. (2011). The potential of feeding goats sun dried rumen contents with or without bacterial inoculums as replacement for berseem clover and the effects on milk production and animal health. Int. J. Dairy Sci., 6(5): 267-277

18. MAFF. (1975) .Ministry of agriculture, fisheries and food, energy allowances and feeding systems for ruminants. Tech. Bull. 33. Her Majesty's Stationery Office. London, UK.

19. Mondal, S., Haldar, S., Samanta, I., Samanta, G. and Ghosh, T.K. (2013). Exploring nutritive potential of undigested rumen contents as an ingredient in feeding of goats. Anim. Nutr. Feed Technol., 13:79-88.

20. Nasser, A.K., Shams Al-Dain, Q.Z., Mahmood, A.A., Aboo, N.Y. (2012). Effect of partial replacing of dry rumen content instead of barley in calf starter ration and age on production performance, hematological and biochemical parameters of growing local calf before weaning.Mesopotamia J. of Agric. 40(2): 58-68.

21. Olafadehan, O.A., Okunade, S.A. and Njidda, A.A. (2014). Evaluation of bovine rumen content as a feed. Trop. Anim. Health Prod., 46: 939-945.

22. Osman A.A.B., Hamed, A.H.M. and Elimam, M.E. (2015).Effects of dried rumen contents level in rations on the performance of Shugor desert sheep in HalfaElgadeda, Kassala state, Sudan.Anim.Rev., 2(4): 81-86.

23. Osman, A.A.M.O. and Abass, H.A.M. (2015). Processed animal waste as feed for Sudanese desert sheep. Int.J.Adv.Multidiscip. Res., 2 (7):12-17.

24. Rao, N. M. and Fontenot, J. P. (1987). Ensiling of rumen contents and blood with wheat straw. Anim. Feed Sci. Technol. 18:67-73 
25. Rezakhani, A.H., Abbasi, A., Nejad, N.T., Asadi, M.R. and Ferdowsi, H.R. (2008). Determination of nutritive value of dried rumen contents.Proceedings of the $15^{\text {th }}$ Congress of FAVA - OIE Joint Symposium on Emerging Diseases. FAVA 27-30 October 2008, Bangkok, Thailand.

26. Rios-Rincon, F.G., Bermduez-Hurtado, R.M., Estrada-Angulo, A., Juarez-Reyes, A.S. and Pujol-Manriquez, C. (2010). Dried rumen contents as a substitute for alfalfa hay in growing finished diets for feedlot cattle. J.Anim.Vet.Adv., 9(10):1526-1530.

27. Salinas-Chavira, J.,Domínguez-Muňoz, M., Bernal-Lorenzo, R., García-Castillo, R.F. and Arzola-Álvarez, C.(2007). Growth performance and carcass characteristics of feedlot lambs fed diet with pig manure and rumen contents. J. Anim. Vet. Adv., 6(4):505-508.

28. SAS (2004). SAS/STAT user's guide: Version 8.1 Edition .SAS Institute Inc., Cary, NC, USA.

29. Talib N.H., Mabrouk, A.A., Mohamed, A.M., Rahama, B.M. and Sulieman, Y.R. (2016). The utilization of rumen contents-sorghum stover silage in diets for ruminant (physical, chemical and ruminal degradation characteristics). Sust J. Agric. Vet. Sci., 17(1):25-31.

30. Van Soest, P.J., Robertson, J.B. and Lewis, B.A. (1991). Methods for dietary fiber, neutral detergent fiber and non-starch polysaccharides in relation to animal nutrition. J. Dairy Sci., 74: 3583-3597. 